The original publication is available at the publisher's web site: http://dx.doi.org/10.1057/jibs.2009.28

\title{
Wary managers: Unfavorable environments, perceived vulnerability, and the development of trust in foreign enterprises in China
}

\author{
Lai Si Tsui-Auch ${ }^{1}$ and \\ Guido Möllering ${ }^{2}$
}

\author{
${ }^{1}$ Nanyang Business School, Nanyang \\ Technological University of Singapore, \\ Singapore; ${ }^{2}$ Max Planck Institute for the Study of \\ Societies, Cologne, Germany
}

\section{Correspondence:}

LS Tsui-Auch, Nanyang Business School, Nanyang Technological University of Singapore, Nanyang Avenue, Singapore 639798, Singapore.

Tel: +65 67906132;

Fax: + 65 67913697;

E-mail: alstsui@ntu.edu.sg

\begin{abstract}
Vulnerability is salient among international managers, who tend to be wary when operating in transition economies like China. Systematic research is lacking, though, on how the local environment influences foreign managers' perception of vulnerability, and how foreign managers can develop trust even when their perceived vulnerability is high. We conducted in-depth case studies of two foreign-controlled enterprises in China, and developed a theoretical model that links perceptions of the macro-level environment to micro-level management. Our results illustrate the antecedents and consequences of perceived vulnerability and the processes of trust building in unfavorable environments. Through comparative analysis of the two cases, we found that the foreign managers' perceived vulnerability was shaped by the institutional, technological, and market conditions of the local environment, and we learned how this perceived vulnerability influenced their trust in the local workforce and the joint investment in formal and social control they used in building trust. The effect of perceived vulnerability on trust was moderated over time when the implementation of control was combined with active investments in trust, which led to behavioral changes on the part of the local employees, which in turn increased their trustworthiness. The implications of these findings are discussed.
\end{abstract}

Journal of International Business Studies (2009) I-20. doi: I 0. I057/jibs.2009.28

Keywords: China; trust; managing foreign operations; institutional environment; institutional theory; primary data sources

\section{INTRODUCTION}

International business scholars and practitioners are particularly attuned to the variety of environmental conditions in which organizations are managed. In foreign and transitional environments the issue of vulnerability is particularly salient, while trust is both valuable and difficult to attain (e.g., Zaheer \& Zaheer, 2006). It is not well understood, though, just how varying local conditions influence the level of perceived vulnerability among foreign managers and the way in which they can develop trust in the local workforce (Boisot \& Child, 1999). This is relevant to international managers, who are expected to achieve high performance with local workforces under varying conditions (Henisz, 2003; Orr \& Scott, 2008).
Received: 30 April 2008

Revised: 19 November 2008

Accepted: 21 November 2008

Online publication date: 7 May 2009 
Foreign enterprises in transition economies such as China (Luo \& Peng, 1999) represent a prime example of a practical setting in which macro-level developments of societal transformation and globalization affect micro-level practices of internationalization and the management of firms in foreign countries in the midst of major changes (Boisot \& Child, 1996; Tsui, Schoonhoven, Meyer, Lau, \& Milkovich, 2004). Managers are bound to feel more vulnerable in such contexts. Fearing a lack of protection for the interests of foreign enterprises in China, many foreign managers are wary of opportunism among the local subordinates, as manifested in fraud, corporate espionage, piracy, and product imitation (Boisot \& Child, 1999; Economist, 2003a, b, 2007; Marsh, 2004).

Although the press occasionally highlights perceived vulnerability (Economist, 2004, 2007), there is a lack of systematic studies on its macro-level antecedents and micro-level consequences within foreign enterprises in China. Following Boisot and Child (1999), organizations are seen as "adaptive systems" that need to respond to the complexity of their environment, but the link between external conditions and the development of internal relations is severely underexplored as a managerial issue. To address this problematic, we present in-depth field studies of two foreign enterprises in China. We examine how their managers perceive the national and regional environments in China and how they develop trust in their local workforces. Qualitative research is well suited to fathom the complex, contextual, and dynamic nature of these issues (Edmondson \& McManus, 2007).

The purpose of our article is to explore the macrolevel antecedents that make foreign managers feel vulnerable in relation to the local workforce within their enterprises, and the consequences of perceived vulnerability for the ways these managers develop trust in their local workforce at the micro level over time in an unfavorable macro environment. The article is organized as follows. First, we review the relevant literature, specifying the conceptual foundation for our work and the unresolved issues it holds. Second, we state our research questions and describe the research design, case selection, data collection, and analytical methods that we have used. Third, we present analyses of two cases that provide the basis on which to generate a theoretical model. Finally, we discuss the theoretical contributions and future research directions.

\section{LITERATURE REVIEW AND CONCEPTUAL FOUNDATION}

\section{Macro-Level Antecedents of Perceived Vulnerability}

Our analysis of the macro-level antecedents of perceived vulnerability in China builds on institutional theory and resource dependence theory. The rationale is that foreign managers may feel more vulnerable if they lack institutional legitimacy and protection as well as secure access to key local resources.

Theoretical insights from institutional perspectives have increasingly been used to study multinational enterprises (e.g., Henisz \& Swaminathan, 2008; Kostova, Roth, \& Dacin, 2008). Institutions can be defined and conceptualized broadly as the regulative, normative, and cultural-cognitive rules that are commonly accepted and followed in a society (Scott, 2008). These rules can be highly formalized, as for example in law, or relatively informal, such as cultural norms of appropriate behavior and patterns of interpretation learned in socialization processes (North, 1990; Scott, 2008).

Among the formal institutions, the legal framework is of fundamental concern to foreign enterprises operating in emerging economies. Despite the continuous legal reforms, the implementation of laws in China remains a primary source of uncertainty for foreign enterprises (Tsang \& Yip, 2007), as the law there is mainly an instrument of the state apparatus (Lubman, 1995), and is subject to variations in local interpretation (Boisot \& Child, 1999). So far, most authors who discuss the legal system in China focus on how this perception of uncertainty affects the strategy of foreign firms. Few have examined how the institutional environment affects relationship building after a strategy of operating in China has been chosen (e.g., Child \& Möllering, 2003). In this article we explore the interface between the macro-institutional environment and the micro practices within foreign enterprises, following up on the acknowledged, but currently unanswered, research question of how institutions influence the organization of local subsidiaries (Henisz \& Swaminathan, 2008). This is the first step toward understanding how micro practices can be adapted to compensate for unfavorable macro influences.

Institutional theorists argue that cultures change amid political, economic, and social transformation, though often slowly and with great resistance (Child, 2000; Tsui-Auch, 2004). As a result of the 
weakening control of both traditional values and Communist ideology amid the rapid social and economic upheaval in China, there have been ongoing cultural changes (Kwong, 1994; Wang, 2005). Ralston, Egri, Stewart, Terpstra, and Yu (1999) find evidence of a shift in the attitude of Chinese people across generations toward the Western values of individualism and materialism. They surmise that today's Chinese managers are more likely to take risks in the pursuit of profit, even when these actions conflict with traditional ways, and to move to where the best opportunities are perceived to lie. In addition, regional differences in values may exist. In our study we explore the foreign managers' perceptions of the national and regional socio-cultural environments of China.

Institutional theory is a major point of reference for gauging foreign managers' perception of the Chinese institutional environment, but it has limitations that we seek to address. First, institutional theory requires further development when it comes to unfavorable environments such as those encountered by foreign managers in China. On the one hand, a typical neo-institutionalist response tends to emphasize institutional constraints and downplay the role of managerial agency to deal with such constraints (for a summary, see Child, 2000). On the other hand, a typical institutional entrepreneurship stance tends to inflate the role of managerial agency in changing the environment (Lawrence \& Suddaby, 2006). Although research has shown that some multinationals are able to exert a certain influence on Chinese national and local governments (Child \& Tsai, 2005; Krug \& Hendrischke, 2008), most foreign managers in China might not be in a position to exercise strong agency in changing institutions in the short and medium terms (Boisot \& Child, 1999; Economist, 2003a, b, 2007). In this study we investigate the ways in which foreign managers can exercise managerial agency to deal with the macro-institutional impact within the enterprise, even if they are not in a position to change their environment. In other words, if the macro antecedents to perceived vulnerability are not amenable to managerial influence, managers may still find ways to make vulnerability tolerable within their enterprises, that is, to build trust.

Second, institutional theory has its limitations, as its primary focus is placed on rules of the game (North, 1990) with reference to regulative, normative, and cultural-cognitive elements (Scott, 2008). Resource dependence theory (Pfeffer, 1982) rightly points out that firms not only require the legitimacy gained from adhering to rules but also depend on a variety of resources from their environments, such as technology, knowledge, market revenue, and labor (Boisot \& Child, 1999). Essentially, resource dependence theory points to the task environment of foreign firms in addition to their institutional environment. This theoretical stream provides orientation for what makes an environment more or less favorable according to the scarcity of the required resources and the resulting competition over resources between firms. It also leads us to consider that some firms are more dependent on local resources than others.

However, resource dependence theory also has its limitations. First, the approach has been usefully extended to capture firms' strategic responses to environments (Oliver, 1991), but it usually does not consider the internal organizational implications of these strategies. Second, an issue that is currently underdeveloped in this theory, and which is most evident in the technological and market environments of China, is the possibility that a firm faces not only scarce resources in its environment but also the theft of its own resources. For example, several authors highlight that foreign companies fear leakages of unprotected innovations or knowhow when operating in transition economies, which may eventually threaten their competitive positions in the local market and even in their home markets in the longer run (Boisot \& Child, 1999; Steensma, Barden, Dhanaraj, Lyles, \& Tihanyi, 2007). In this study, we explore the implications of technological and market conditions for the internal strategies of foreign enterprises.

As the foreign managers in China face unfavorable institutional and task environments, possibly to different degrees, to what extent do they feel vulnerable in relation to the local workforce? What managerial agency would they exercise to handle such externally driven vulnerability and develop trust in this workforce internal to their enterprises?

\section{Perceived Vulnerability}

The concept of perceived vulnerability is central to our study. It emerged in the research process that the link between the Chinese macro environment and the foreign managers' daily micro challenge of creating value with the local workforce lies in the basic human condition of being more or less vulnerable to others. Although vulnerability has attracted managerial attention in recent years, not least because of some dramatic external threats, 
such as terrorist attacks or natural catastrophes (Busby, 2006; Sheffi, 2005), research on this topic in international business studies is scarce. The current literature on vulnerability (exemplified by Sheffi, 2005) mainly examines resilience in response to exceptional disruptions, but neglects the "more mundane" (Boisot, 2007: 218) vulnerability encountered in everyday organizational life. With the exception of Lapidot, Kark, and Shamir (2007), who study the impact of situational vulnerability on trust empirically, vulnerability is not theorized as an antecedent to managerial practices. In our research we examine the environmental impact on the perceived vulnerability of foreign managers, and the effect of vulnerability on the development of trust in the local workforce.

Alwang, Siegel, and Jørgensen (2001) offer a useful definition of vulnerability $(V)$, which includes not only the potential magnitude of the loss $(L)$ but also the probability of the attack $(p)$ and the victim's ability to cope with it $(C)$, producing a simple heuristic where $V=p L-C$. The values of the variables may be either ascribed by an observer or perceived subjectively by the potential victim. We focus on perceived vulnerability, emphasizing the part played by subjectivity in the extent to which foreign managers fear that locals can cause a loss of company resources or do harm to the firm's competitive position. This means that the same environmental conditions can be construed differently by different managers and different firms in terms of vulnerability. This is because the relevance of certain environmental elements and the ability to cope with local threats may vary across foreign firms (e.g., Henisz, 2003).

Our conceptualization of perceived vulnerability includes only the perceived magnitude of the potential loss, mediated by the ability to cope, and not the expected likelihood that any harm will occur. This is analytically important, because managerial agency enters where the externally conditioned potential harm is averted by internally managed processes of trust development. People who trust still feel vulnerable, but the more they trust the less they expect to actually be harmed (Möllering, 2006).

\section{Trust}

Vulnerability is a precondition for trust to be an issue, and trust is a way of dealing with vulnerability (Baier, 1986; Möllering, 2006). Hence we investigate the interaction of trust and vulnerability within enterprises managed by foreign firms in the Chinese context. When examining trust in our empirical context, we study the generalized trust of foreign managers in their local workforce within their enterprises. We adopt the widely accepted definition by Rousseau, Sitkin, Burt, and Camerer (1998: 395) of trust as a "psychological state comprising the intention to accept vulnerability based upon positive expectations of the intentions or behavior of another", which subsumes the "willingness of a party to be vulnerable to another party" highlighted by Mayer, Davis, and Schoorman (1995: 712), and also Baier's (1986: 235) earlier conception of trust as "accepted vulnerability to another's possible but not expected ill will". It is important to note that the willingness to be vulnerable in trust should not be understood as the willingness to be hurt, but as the expectation that no harm will be done, although it could be done (Möllering, 2006).

We recognize that trust concerns the competence as well as the benevolence of the trustee, building on Barber's (1983) distinction between technically competent performance and fiduciary obligation. Competence captures the confidence that the trustee has the required skills, and benevolence expresses the expectation that the trustee has good intentions toward the trustor and will not behave opportunistically. The inclusion of both competence and good intentions is well established in trust research (e.g., studies building on Mayer et al., 1995; Möllering, Bachmann, \& Lee, 2004), and is important for our analysis of foreign managers in China.

A particularly important question about the relationship between perceived vulnerability and trust is whether vulnerability comes before or after trust, or both (Bigley \& Pearce, 1998). In the Mayer et al. (1995) model, "perceived risk" enters after trust has been reached, moderating the relationship between trust and risk-taking behavior. In the authors' view, the trustor is assumed to start out from a neutral position from which he or she decides to increase or decrease vulnerability. Lapidot et al. (2007), however, argue that trustors will not be in a neutral position but sense their vulnerability in a given context ex ante, which may affect their readiness to trust. Our study will seek to clarify the relationship between vulnerability and trust.

\section{Control}

The exercise of control can be seen as an alternative managerial response to vulnerability besides trust. 
Among the different types of control, a review of our field data in the initial stage of field research showed that the enterprises relied largely on formal control and social control (Cardinal, Sitkin, \& Long, 2004; Inkpen \& Currall, 2004). Formal control mechanisms include officially sanctioned, externalized, overt mechanisms such as written rules, standard operating systems, legalistic remedies, and rewards and penalties. In contrast, social control guides behavior through informal rules, norms, and values that people have internalized through socialization, training, and spontaneous interaction. In the enterprises that we have studied, control is often evident in human resource management (HRM) practices. In particular, the use of expatriates can be read as a sign of tightening control, while the reliance on local managers (referred to as localization by HRM specialists) is a sign of relaxing controls (Delios \& Björkman, 2000; Lu \& Björkman, 1997).

Whereas the relationship between vulnerability and control is relatively clear, that between trust and control continues to be controversial (Das \& Teng, 1998; Long \& Sitkin, 2006; Möllering, 2005). Inkpen and Currall (2004) argue that control that is based on asymmetric power may be a substitute for trust that stems from shared values and norms. Zucker (1986) contends that trust and control are complementary, and that the implementation of control may foster trust, and vice versa - with the resultant managerial challenge being to achieve a balance (Long \& Sitkin, 2006). In the study reported, we explore how foreign managers use control and whether, in their Chinese enterprises, it is a substitute for trust, an enhancer of trust, or both.

\section{Trust Building}

How can trust be developed, even when a trustor perceives a high level of vulnerability that initially calls for tighter control instead of trust? Much trust research has been devoted to analyzing perceived trustworthiness as an antecedent to trust (e.g., that based on Mayer et al., 1995), because trustworthiness is supposed to be the mechanism that drives positive expectations in the face of vulnerability.

Several authors, however, recognize that trust is not only a passive reaction to the trustworthiness of trustees, but also the result of an active investment in trust by the trustors themselves (e.g., Williams, 2007). In their study of Hong Kong managers' trust in mainland Chinese staff, Child and Möllering (2003) find that active investment in trust through personal rapport, careful recruitment, and the transfer of practices promotes trust building. In our empirical analysis we capture foreign managers' activities that might shape the perceived trustworthiness of the locals and aid the development of trust.

Prior research also points to the principle of gradualness (Luhmann, 1979), whereby trust building starts with small steps that enable actors to establish each other's basic trustworthiness and build deeper trust relationships over time (e.g., Lewicki \& Bunker, 1996; Rousseau et al., 1998). In a review of this work, Lewicki, Tomlinson, and Gillespie (2006) discuss transformational models of trust development which generally predict that trust relationships evolve from a more calculative and control-oriented stance to a more relational and identification-based form. We build on this literature and pay particular attention in our case analyses to the question of whether control becomes less important as trust increases, and whether certain phases of transformational models can be skipped.

\section{RESEARCH QUESTIONS, DESIGN, AND METHOD}

As the literature review shows, the processes of compensating for unfavorable external conditions through internal management in a transition economy are not yet well understood. We have therefore aimed to explore two research questions empirically:

(1) What environmental factors make foreign managers feel vulnerable in relation to the local workforce within their enterprises?

(2) How do foreign managers in unfavorable environments handle their perceived vulnerability and develop trust in their own employees?

Our research has not been designed to test hypotheses, but to generate a theory to address the two questions. We acknowledge that our fieldwork in the spirit of grounded theory is presented in a more sequential and theory-driven manner than it was carried out, owing to conventions on how we write papers (see Suddaby, 2006). We emphasize that the theoretical model we subsequently generate in this article is the outcome, not the premise, of the empirical work and analysis that we describe in this section.

\section{Research Design}

As vulnerability and trust are highly delicate, elusive, and sensitive phenomena unfolding in 
processes over time, we believe that a qualitative study with intensive fieldwork is able to capture them more effectively than a survey-based study. In particular, we have chosen a comparative case study approach because it permits the induction of richer explanations more than a single-case study approach (Yin, 2003). In terms of methodological fit (Edmondson \& McManus, 2007), our qualitative approach matches the nascent state of theorizing externally caused vulnerability and its relationship with internal trust and control. It is also an "insideout" approach best suited to achieve "contextualization" (Tsui, 2006).

\section{Case Selection}

We looked for cases in China with enough variance in the institutional and task environments that might shape perceived vulnerability. In particular, there might be regional differences (Child \& Stewart, 1997). We succeeded in gaining full access to two enterprises, namely Kunling and Hyform, which show sufficient contrast in these environments. Kunling has been operating in Kunming, the capital city of Yunnan province in the southwestern part of China. Hyform has been operating in Dongguan, Guangdong province along the southeastern coast, which has had a longer history of foreign direct investment. The former has relied on the local market, whereas the latter has focused on exports. The former has possessed advanced proprietary knowledge whereas the latter has not.

\section{Data Collection}

We collected both factual information and more open-ended narrative data based on an interview guide; the entire process took us more than 4 years (from early 2002 to mid-2006) from field preparation to project completion. Two teams of research students with three members each - all of whom were bilingual in Chinese and English - were guided to conduct the field studies in two phases over an average period of 20 months for each case.

In the initial phase the research teams conducted preliminary interviews with managers in the headquarters of the two enterprises to identify the research focus and build rapport in preparation for the field studies. During this initial exploration we realized that it was primarily the local managerial and supervisory employees who were given access to strategically vital assets and hence were in a position to subject the foreign managers to vulnerability. We thus confined our focus to exploring foreign managers' generalized trust particularly in this section of the local workforce rather than the local workforce as a whole, and identified this group for in-depth interviews in the latter phase. Both enterprises are small or mediumsized enterprises (with 250 local employees in Kunling and 490 local employees in Hyform) for which field studies of delicate relationships such as trust at the individual level are feasible.

The latter phase consisted of plant visits, field observations, the collection of written and archival materials, semi-structured interviews with selected respondents in the Chinese operations, and informal conversations with other local employees, customers, and government officials. Altogether, our teams conducted 102 formal interviews with 77 informants, who were selected on the basis of formal, snowball, and opportunistic sampling methods. Table 1 summarizes the organizational backgrounds of our informants and the number of interviews conducted. We carried out lengthy interviews of up to five hours each, with many of them taking place at the informants' homes or in restaurants.

We agree with Greenwood and Suddaby (2006) that often in qualitative research the process of data collection is not neatly ordered, and hence an opportunistic approach is required as events unfold and unexpected insights occur, matching in many ways the notion of abductive research (see Van Maanen, Sørensen, \& Mitchell, 2007). Our field research took us on an "iterative, cyclic learning journey" (Edmondson \& McManus, 2007: 1174). Nevertheless, we observed procedures that would enhance the validity and reliability of our research (Schweizer, 2005; Yoshikawa, Tsui-Auch, \& McGuire, 2007). To enhance construct validity, we relied on the triangulation of the data with other sources whenever possible. We exercised due diligence by discussing the core issues uncovered from our field data (while ensuring confidentiality) with 18 foreign investors, managers, and members of industrial associations, who confirmed that our data reflected an important part of the organizational reality in the Chinese operations of foreign enterprises. The external validity of each case study was improved by performing a comparative analysis of our findings. The internal validity of each case study was boosted by conducting multiple interviews with the same respondents and maximizing the internal consistency of the interviews. We addressed the issue of reliability by enforcing a detailed case study and interview protocol and by setting transcription standards. We tackled 
informant bias through the use of both retrospective and real-time data (Eisenhardt, 1989). We also assured the informants of their anonymity in order to promote candor.

\section{Data Analysis}

We guided our research teams to conduct an interpretive analysis of content in the spirit of grounded theory (Glaser, 1998; Kotabe, Parente, \& Murray, 2007), which led us to construct a theoretical model in four steps. The content analysis of the qualitative data was performed through an iterative, interpretive approach of moving between data and literature to identify a chain of evidence and develop a coherent explanatory framework (Shapiro, Ozanne, \& Saatcioglu, 2008). First, we uploaded all the transcribed responses from informants and documents from secondary sources into a database for each case. Second, we conducted a within-case analysis to compare data across all interviews and documents, and we identified themes and constructs (Miles \& Huberman, 1994). We constantly revisited our data when insights about the factors shaping vulnerability and the process of developing trust emerged in each case. Third, we conducted a cross-case analysis

Table 1 Organizational backgrounds of formal interview informants and number of interviews

\begin{tabular}{|c|c|c|c|c|}
\hline & Departments & Designations & $\begin{array}{l}\text { No. of } \\
\text { informants }\end{array}$ & $\begin{array}{l}\text { No. of } \\
\text { interviews }\end{array}$ \\
\hline \multirow[t]{13}{*}{ Kunling } & Finance & Finance controller, ${ }^{*}$ secretary, manager, worker & 4 & 7 \\
\hline & Marketing & Manager, worker & 2 & 2 \\
\hline & Purchasing & Manager, secretary, worker & 3 & 2 \\
\hline & General affairs & $\begin{array}{l}\text { Department head of drivers, driver, head of } \\
\text { canteen }\end{array}$ & 3 & 3 \\
\hline & Human resources & Manager & 1 & 2 \\
\hline & Management information system & Manager, ${ }^{*}$ worker & 2 & 4 \\
\hline & $\begin{array}{l}\text { Production planning and inventory } \\
\text { control }\end{array}$ & Manager & 1 & 2 \\
\hline & Production & Manager, ${ }^{*}$ worker & 2 & 3 \\
\hline & Quality control & Head, * manager & 2 & 3 \\
\hline & Slitting and packaging & Manager & 1 & 1 \\
\hline & Warehouse & Manager & 1 & 2 \\
\hline & Engineering & Supervisor & 1 & 1 \\
\hline & Public relations & Manager, ${ }^{*}$ worker & 2 & 2 \\
\hline \multirow[t]{18}{*}{ Hyform } & Singaporean headquarters & Managing director, ${ }^{\star}$ production consultant* & 2 & 4 \\
\hline & General manager's office & $\begin{array}{l}\text { General manager, vice general manager, } \\
\text { secretary }\end{array}$ & 3 & 11 \\
\hline & Finance & Head, worker & 2 & 5 \\
\hline & Human resources & Head, manager & 2 & 2 \\
\hline & Administration & Head, manager, supervisor & 3 & 3 \\
\hline & Sales & Head, manager & 2 & 2 \\
\hline & Engineering & Head, manager & 2 & 2 \\
\hline & Quality control & Head, manager, supervisor & 3 & 3 \\
\hline & Production & Head, manager & 2 & 5 \\
\hline & Oil press & Head, manager, supervisor, worker & 4 & 4 \\
\hline & Spray paint: silicon rubber & Head, manager, supervisor, worker & 4 & 4 \\
\hline & Spray paint: rubber & Head, manager, supervisor, worker & 4 & 4 \\
\hline & Laser etching & Head, manager, supervisor & 3 & 3 \\
\hline & Printing & Head, manager, supervisor & 3 & 3 \\
\hline & Assembly & Head, manager, secretary, supervisor, worker & 5 & 5 \\
\hline & Packaging & Head, manager, supervisor, worker & 4 & 4 \\
\hline & Mold insertion & Head, manager, supervisor, worker & 4 & 4 \\
\hline & Total & & 77 & 102 \\
\hline
\end{tabular}

Note: Those marked * are foreign managers. 
(Eisenhardt, 1989; Tsui-Auch, 2005). We held no prior hypotheses and compared the cases by identifying similarities and differences (Kotabe et al., 2007). We found that the Kunling case illustrates a high level of perceived vulnerability and a heavy reliance on control, whereas the Hyform case shows a low level of vulnerability and a strong reliance on active investment in trust. The comparative case analysis led to additional data collection and further analysis. Finally, we formulated a model with tentative arguments to show the associations between constructs and patterns. Iterating between theory and data, we fine-tuned the constructs and built the most defensible arguments (Yin, 2003).

\section{FIELD STUDY RESULTS}

In this section we present a summary of the withincase analysis of each enterprise that provides a basis on which to conduct a cross-case analysis and to generate a theoretical model in the next section.

\section{The Company Kunling: A Case of High Vulnerability}

Kunling is a wholly foreign-owned subsidiary of an Indonesian conglomerate. It was established in 1994 to produce high-quality biaxially oriented polypropylene (BOPP) film for packaging, which is marketed throughout the world under the brand name Ilene. While Kunling was in a favorable position to benefit from the rapidly growing local market, its foreign managers felt that they were highly vulnerable to their local subordinates in three respects: the failure to meet production quality standards, fraud and collusion, and in particular the leaking of classified information.

\section{Environmental factors shaping the high levels of perceived vulnerability. All the foreign managers we interviewed felt that their local workforce was unreliable when it came to task performance. One of them illustrated the point: \\ Don't expect miracles from operators to managers. Don't expect that they come in and can reach the standards.}

The foreign managers' perception of their local workforce was influenced by their perception of the institutional environment. They expressed a low level of confidence in the educational and human resource training systems, which still bore the marks of centralized planning and the Cultural
Revolution. A foreign manager explained:

It's the whole system, [and] history of the Cultural Revolution. In those days, everybody just played a part, or most people didn't even play their part and yet they got food, the same pay, and the same reward. So, why work so hard? ... The next thing [was] the training provided in China ... The teachers in China [have] enjoyed a very low status ... Their pay [has been] among the lowest. They [only] talked a lot about morale, theory ... People [saw it as further] propaganda like during the Cultural Revolution....

All the foreign managers explained that education and training remained rather ineffective in equipping people with reliable competencies and quality commitment, given the low status of teachers and the cynicism of trainees toward the theories and morals imparted.

Besides the educational and training institutions, the foreign managers were wary of the rise of a materially oriented culture that might derail individuals, increasing the likelihood of opportunistic behavior. One of the foreign managers recalled:

When Kunling was founded, the board members were wary of being cheated by the locals... . They were worried about not being able to constantly monitor and supervise the Chinese managers who might siphon away company funds.

The foreign managers' perceived vulnerability was heightened by cases of embezzlement and collusion within Kunling. A number of local informants acknowledged that embezzlement was a common problem in enterprises operating in their country.

In addition, the foreign managers were perplexed to find that the locals did not honor contracts, which by international standards represent a structural safeguard. A manager revealed:

In Kunling, there were managers who ... do not honor contracts ... There is no difference between the younger and old generation [in this matter]. To a local, the value of life is to ... live more comfortably, [to have] more money, [and to be] rich.

Even the local informants admitted that the local employees were "known for violating contracts".

The wariness of foreign managers was further reinforced by the problematic legal framework in which sanctions against corporate crimes and abuse might not be reliably enforced, and where pursuing litigation and claims was time-consuming. One of them stated:

Even if you go strictly by the law, you would still not be able to accomplish anything. ... If a contract is violated, there are usually two types of action. One is to accept it and choose not to take any action, and the other is to take 
corrective action, which usually involves a lot of time and effort and may not yield any result.

The perceived vulnerability of the foreign managers was particularly high in relation to the local subordinates who were exposed to the advanced proprietary knowledge of the company, that is, the formulae for mixing the basic raw materials. One of the foreign managers revealed:

The formulae are our most critical weapons that allow us to fight better... If our formulae [were] leaked, our local competitors [would] copy our products and weaken our competitiveness. Our company [did not file] a patent before [it introduced] the products to the market [as it had no confidence in the local patent protection system]. If a competitor got hold of the formulae and manufactured similar products, there would be no way that we could sue [it] for compensation. Our competitors could sell similar products at cheaper prices by evading the payment of the value added tax ... China is our major market. A reduction in sales in this market would affect our growth.

The perceived vulnerability was heightened by low barriers to entering the BOPP film industry. The Yunnan provincial government identified this as one of the key industries, and financially supported state-owned or related enterprises to acquire foreign technology (Hooghe, 1994). A popular means for local enterprises to prompt technological learning was through poaching skilled personnel from foreign-owned enterprises. The foreign managers of Kunling were particularly worried about such risks, because they imported state-of-the-art production technology from Germany and were constantly upgrading the skills of the locals. One of them said:

This industry can easily be entered by anyone. In fact, a [number] of local bosses have set up factories to run similar businesses in China ... We [have] very keen competition, and these competitors really dig up information from our staff ...

A local human resource manager recalled incidents about the poaching of skilled personnel by local competitors:

Once, an assistant production manager was poached by a [local] competitor. There were also workers who [quit Kunling and joined] a major [local] competitor.

The foreign managers of Kunling felt vulnerable because the venture supplied products primarily to local customers with whom its local managers could probably develop direct contacts and who could easily be poached by competitors. A foreign manager and a local manager illustrated such anxiety in turn:

If we leave [the information about costing] to the local staff, eventually they might take away our business ...

If our competitors get to know the information such as the names of customers, their addresses, and quantities of orders, it will be easy for them to know which customer to poach ...

The environmental conditions of Kunling meant that the locals were in a position to do much damage to the firm, which explains the high level of perceived vulnerability on the part of the foreign managers. Although Kunling belonged to a large Indonesian conglomerate, it could hardly influence the local government's industrial policy. In addition, it was highly dependent on local resources, and hence the local conditions had a strong effect on the perceived vulnerability of its foreign managers. Therefore these mangers started out with a very low level of trust in the workforce within their own enterprise.

Use of control supplemented by active investment in trust. Given the high level of perceived vulnerability and low level of trust, how could the foreign managers come to trust the locals over time? The Kunling case shows that trust can be developed with effective controls that are supplemented by active investment in trust.

To cope with the vulnerability, elaborate formal control mechanisms over production, financial management, and especially over information sharing were developed at the firm, according to both foreign and local informants. For example, with regard to information sharing, the topmost management positions of departments that dealt with classified information were not localized till 1999. For the post of material mixing supervisor, who handled the formulae that constituted the proprietary knowledge, only one local was trained, but his full access to these formulae was subject to approval by a foreign factory manager. During our plant visits, we read a number of notices such as "unauthorized personnel are forbidden to enter the raw materials mixing room" and "unauthorized personnel are forbidden to enter the office of the Head of $Q C / R \& D "$. The penalty for a violation of these rules was severe, according to the local informants. In addition, a company-wide restriction on the use of information technology was imposed in order to reduce the chances classified information being leaked. 
Nevertheless, the foreign managers understood that too much formal control might demoralize employees, leading to a high turnover of labor. A local marketing manager gave an analogy: "You cannot afford to grasp the sand in your hand too tightly, as the more you grasp it, the faster it seeps away from you". In Kunling, formal control was often supplemented by social control and investment in trust. To transfer corporate values and skills, the foreign managers offered in-house training to all newly hired employees, socializing them into values of company loyalty and quality commitment. Based on our field observations, social interactions (at work, in training courses, and at social gatherings in restaurants and karaoke lounges) provided the foreign managers with opportunities to build rapport and gauge the values of their subordinates. The investment in training and socialization demonstrates not only the foreign managers' intention to exercise vulnerability-reducing control but also their willingness to actively invest in trust relationships. The resources required might be wasted in the event of a trained employee quitting the company to seek greener pastures; nevertheless, the foreign managers hoped that these investments would yield positive returns in the sense that the locals would value the training and bonding and reciprocate in their behavior by showing enhanced competence and commitment.

Change in perceived trustworthiness. Over time, the locals' behavior changed as they complied with the formal control and responded positively to social control and trust building. As a result, their perceived trustworthiness was enhanced. One foreign manager said:

\footnotetext{
We feel that our employees definitely [have become] more reliable [and] trustworthy over time. This trustworthiness has slowly increased as we have got to know each other better. There [are] steps to observing the newly hired ... They must be [monitored] by assistant supervisors, supervisors, and managers ... They are now well trained [and] hardworking. They know what the customers want. After four to five years' training and operation, the Chinese [have improved] the capability of the machines and demonstrated the new capability to the Indonesians.
}

The longer the employees served, the more opportunities they had to receive training and thereby demonstrate their reliability and willingness to learn, improve their performance, and build a track record, thus increasing their trustworthiness in the eyes of the foreign managers and subsequently earning their trust. The offer of training turned out to be popular among the locals, and the enforcement of monitoring was effective, as seen in positive behavioral outcomes in terms of meeting customer demand and reversing the technological transfer back to the mother country.

The coexistence and interaction of trust and control. Trust in the local organizational members subsequently increased as a result of an increase in their perceived trustworthiness, despite a persistently high degree of perceived vulnerability in relation to the local workforce. However, the increase in trust did not drive out the use of controls. For example, whereas the foreign managers removed some rules on restricting the sharing of classified information with the local managers, they remained guarded against the abuse of critical resources. One foreign manager explained:

Trust in the locals ... definitely increased over time ... But in my organization, [there is] a lot of corruption going on, a lot of misconduct going on. The boss will have to [stay] in China to oversee [the operation, or] there will be a lot of monkey business going on behind his back.

\section{The Company Hyform: A Case of Low Vulnerability}

A Singaporean firm that manufactures customized plastic components set up a joint venture, Hyform, in 2002 with three Chinese partners. The Singaporean firm had an equity interest of $54 \%$, and the Chinese partners owned the remainder. The managing director of the Singaporean firm assumed the post of managing director of Hyform. The Chinese partners assumed the posts of general manager, vice general manager, and finance director.

Factors shaping the low levels of perceived vulnerability. Unlike the foreign managers of Kunling, the two foreign managers of Hyform did not feel highly vulnerable. First, the company did not have any advanced proprietary knowledge to protect. The foreign managers explained that the previously proprietary knowledge about materials and methods of production had become common knowledge to all competitors. In addition, they did not feel vulnerable about technology transfer. One of them revealed:

We mainly send our old equipment there ... We [transfer] the production processes that are more labor intensive [there].

Moreover, the foreign managers of Hyform felt secure, owing to the high entry barriers to their 
industries. In Guangdong province, in which they were operating, there was no industrial policy to foster local industrial development, and hence it would have been difficult for the local Chinese to establish production lines to compete with Hyform. One of them said:

The [financial] investment is heavy ... They've got nothing to gain if they run [away]. Basically, they [come from the working class and] don't have capital to set up [their] own company.

In addition, the enterprise did not depend on the local market as it was established for export. In fact, $90 \%$ of its customers were outside China. Hence the foreign managers were not wary of betrayal by their Chinese partners. One of them elaborated:

The Chinese [partners] ... do not have a direct interface with [the overseas customers]. [Our] customers are reputable, big, and established companies. They will not take advantage of pricing and turn to imitations.

This foreign manager showed confidence in the tertiary education and human resource training system in the region. Guangdong province, in his view, pioneered the attraction of foreign investment and hence had a more enterprising work culture than the inland provinces. In addition, the economic prosperity there generated more resources to strengthen the educational system than did the less developed inland provinces. The foreign manager said:

The university education is up to standard. My managers and accountants have a sense of professionalism and seek future prospects and learning [opportunities] other than focusing on earning money.

Nevertheless, the perception of both foreign managers toward the legal and larger socio-cultural environment was far from positive. One of them expressed the view:

From what I have heard, many of [the Singaporean companies] face a lot of problems like theft. For example, their [local] employees give business to someone else as they can earn commissions ... I heard that in some factories there were [local employees stealing] the company cars or a few hundred thousand dollars. Now China's [legal system], as compared to [that in developed] countries, is less effective ....

The foreign managers' perception did not seem to have come out of paranoia. Two local managers conveyed similar perceptions. However, the foreign managers felt much less vulnerable than their counterparts in Kunling despite the unfavorable socio-cultural and legal environments. Given the limited dependence of Hyform on local resources, there were few chances for opportunistic behavior by the local employees.

Active investment in trust supplemented by control. Given the low level of perceived vulnerability, the foreign managers had a lot of trust in the local partners from the company's inception. The foreigners actively engaged in trust investment by letting them run the whole operation. One of them repeated in different interviews:

The Chinese partners actually run the business themselves .... I don't think my partners will want to set up a company to compete with me.

The use of active investment in trust was confirmed by the local partners. One of them said:

The managing director [i.e., the foreign manager] has a bird's eye view of the business. He has a lot of trust in us. Otherwise, he would manage the company on his own.

It is noteworthy that this seems to be a relationship that started off with a relatively high level of trust that is supposed to take a lot of time to develop. Nevertheless, the active investment in trust was safeguarded by a basic level of formal control, as one foreign manager revealed:

It is not blind trust. We are also protecting ourselves ... We are protected by legal documents. We have the shareholder agreement ... These formal controls are done in Singapore.

He believed that the agreement, which was a formal, legalistic remedy, would reduce the risks of opportunistic behavior on the part of the local partners because its enforcement relied on the reliable legal system in Singapore rather than the unreliable system in China. This access to resources outside China reduced Hyform's dependence on the local context.

Enhancement of perceived trustworthiness. The foreign managers' active investment in trust was reciprocated by the local partners' making personal sacrifices to improve the enterprise. Eventually, this behavior of the locals demonstrated their commitment and competence and subsequently enhanced their trustworthiness, helping them to gain a higher level of trust from the foreign managers, although the foreign managers' perceived vulnerability toward the larger legal and socio-cultural environment remained unchanged. One of the foreign managers explained:

It is hard to enforce legal documents here. If an employee wants to harm the company, then whatever we sign is 
useless ... [My local partners] are trustworthy ... They have made sacrifices for the company [and] devoted effort to improve the company ... These are examples of them trying to gain our trust.

Initially, I went over to China about twice a month. Now [I go there only] once a month ... I also have some presigned documents, which also shows that I trust them that they will do [things] properly.

The coexistence and interaction of trust and control. Even in this case of substantial trust in the local partners, control was necessary. One of the foreign managers clarified:

No matter how much we trust, the primary controls still have to be in place. Having good relations and high levels of trust does not mean that there will be a slackening of control ...

Both the oral clarification and written materials of rules and regulations confirm that there are limits to the substitutability of control by trust. A minimum level of control is actually required to balance trust.

\section{Case Summary}

This comparative study of the two enterprises sheds light on the environmental drivers of vulnerability and the different ways for foreign managers to handle varying degrees of vulnerability (see Table 2 ).

In the case of Kunling, all of the foreign managers interviewed felt highly vulnerable to the institutional, technological, and market environments. Given the high dependence of the enterprise on local resources, these managers had initially a low level of trust in the local workforce. They dealt with their vulnerability by focusing on formal control and supplementing it with social control and active investment in trust. In light of the local workforce's change in behavior as a result of their compliance with control and positive reception of foreign managers' active investment in trust over time, the foreign managers revised their initial perceptions and came to perceive the locals as trustworthy, and subsequently developed trust in the local workforce. Nevertheless, trust did not drive out control.

In contrast, though the foreign managers of Hyform had an attitude toward the larger legal and socio-cultural environment similar to their counterparts in Kunling, they felt much less vulnerable to the local work culture and technological and market environments. The lower sense of vulnerability, mediated by the relatively low level of dependence on the local resources, given their access to (legal and market) resources outside China, allowed the foreign managers to maintain a high level of trust in the local partners within the enterprise. The foreign managers actively invested in trust in the local partners from the company's inception. The local partners reciprocated by making personal sacrifices for the improvement of the enterprise, and this enhanced their trustworthiness further in the eyes of the foreign managers. Nevertheless, active investment in trust was still supplemented by formal control. Ultimately, trust and control coexisted and were not fully substitutable for each other.

\section{GENERATING A THEORETICAL MODEL FROM CROSS-CASE ANALYSIS}

\section{Overview of the Model}

Based on our comparative case analysis, we have generated a model (Figure 1) that captures the theoretical insights that emerged from the qualitative study. In contrast to a theoretically derived model, which can include all kinds of plausible effects, our empirically grounded model is limited to observations and relationships that are revealed in our data (represented by solid arrows in Figure 1). Our case analysis shows the macro-level antecedents of perceived vulnerability and the consequences of such vulnerability for the internal management and intra-organizational relationships of foreign enterprises in China. Nevertheless, in the graphic representation of our model, we include some possible relationships (marked by dashed arrows) that were not directly evident in our study but which suggest interesting feedback loops to be discussed as future research directions.

Our model presents the relationship between environmental conditions, perceived vulnerability, and the internal development of trust in foreign enterprises. The model has two main parts linked by the concept of perceived vulnerability. The first part captures the macro-level antecedents (institutional, technological, and market conditions) of perceived vulnerability among the foreign managers, which is mediated by the foreign enterprise's dependence on local resources. The second part of the model captures the effect that perceived vulnerability has on the foreign managers' trust in the local workforce within the foreign enterprise, and how this leads to the exercise of managerial agency through implementing control and investing in trust. The managerial agency produces 
Table 2 Summary of the cross-case analysis

\begin{tabular}{|c|c|c|}
\hline Constructs considered & Kunling & Hyform \\
\hline $\begin{array}{l}\text { Degree of perceived } \\
\text { vulnerability among foreign } \\
\text { managers }\end{array}$ & High & Low \\
\hline
\end{tabular}

Environmental conditions for perceived vulnerability

Dependence on local resources

Effect of perceived vulnerability on foreign managers' trust in local workforce

Use of control and active investment in trust

Behavior of local workforce

Change in perceived trustworthiness

Coexistence of trust and control
Possession of strategically vital proprietary knowledge

Transfer of the state-of-the-art machinery and advanced skills

Operation in an industry with low entry barriers for local competitors

Total reliance on the local market

Unreliability of the legal-enforcement system in a transition economy

Cultural shift toward the pursuit of personal wealth and self-interest in a transition economy Operation in an inland region characterized by a poor educational infrastructure and a low commitment to work and quality

Strong dependence on local resources and little power to change the local conditions

Low confidence in technical competence and work commitment Strong fear of the leakage of proprietary knowledge, fraud, and collusion

Reliance on formal control Supplementation by social control and active investment in trust

Higher competence after training Greater commitment as a result of socialization

Increase in perceived trustworthiness as a result of the locals' compliance with controls and positive reception of active investment in trust

An increase in trust

Relaxation of formal controls but maintenance of controls over the access of critical resources
The previously proprietary knowledge had become common knowledge to competitors Transfer of labor-intensive process and outdated technology

Operation in an industry with high entry barriers for local competitors

Heavy reliance on the foreign market

Unreliability of the legal-enforcement system in a transition economy

Cultural shift toward the pursuit of personal wealth and self-interest in a transition economy Operation in a coastal region characterized by a good educational infrastructure and a high commitment to work and quality

Access to resources beyond the local despite little power to change the local conditions

Strong belief in technical competence and work commitment

Low fear of opportunistic behavior

Reliance on active investment in trust Safeguard by formal control

Better performance confirms competence Sacrifices confirm commitment

Increase in perceived trustworthiness as a result of the locals' reciprocation to active investment in trust

An increase in trust

Maintenance of basic formal control behavioral outcomes on the part of the local employees, who may (or may not) behave in ways that present evidence to the foreign managers of the locals' competence and commitment. The behavioral outcomes of the locals will affect the level of their trustworthiness in the eyes of the foreign managers, which subsequently moderates the negative effect of perceived vulnerability on trust.
The model shows not only causal relationships, but also development processes over time. The cycle captured in the second part of the model indicates that variables - including the foreign managers' trust in the local employees, managerial agency and its responses, and perceived trustworthiness of the locals - co-evolve so that positive trust building spirals, as observed in our cases, are possible. 
Technological conditions. The different degrees of perceived vulnerability among foreign managers in our cases are also related to two technological conditions - the attractiveness of advanced proprietary knowledge to local competitors, and the need for investments in equipment and skills as indicated in the level of technology transferred. In the Kunling case the possession of strategically vital proprietary knowledge and a high degree of sophisticated machinery and skills transferred to the local operation made the foreign managers wary of corporate espionage. In contrast, the foreign managers of Hyform did not feel vulnerable, as the previously proprietary knowledge had become common knowledge to competitors, and only labor-intensive assembly based on mature technology was transferred to the local operation.

Market conditions. The level of foreign managers' perceived vulnerability also depends on market conditions. These include entry barriers for local competitors who might come into the industry in which the foreign venture is operating, and the attractiveness of local markets compared with export markets. In the case of Kunling, the low level of entry barriers for local competitors, given regional industry policy and the reliance on the booming Chinese market, subjected the foreign managers to greater vulnerability because local competition for product sales, managers, and customers was severe. In contrast, the foreign managers of Hyform did not feel vulnerable, given that the barriers for local competitors striving to enter this industry were higher, and the enterprise was set up for export to customers located outside China.

It is important to note that the perceptions of vulnerability among foreign managers in both Kunling and Hyform were shaped not only by the national legal environment, but also by the specific regional environment, especially in relation to the work culture, the educational system, and industrial policy. As shown by the case data, the foreign managers in Kunling, which is located inland, perceived a higher level of vulnerability than their counterparts in Hyform, who operated on the coast.

\section{The Mediating Effect of Dependence on Local Resources}

Comparing Kunling and Hyform, we find that the impact of the environmental conditions on perceived vulnerability is mediated by the firms' level 
of dependence on local resources. Although both companies are foreign enterprises backed up by multinational corporate groups, Kunling was much more dependent on the local environment than Hyform and hence became more affected by the local conditions. Hyform's lower level of local dependence is evident from its better access to legal and market resources outside China compared with Kunling. Local dependence and its mediating effect can also be a function of the foreign firm's power to influence the local conditions. In our cases, both firms were not in a position to change the local conditions in their favor, but the data suggest that this lack of power was more problematic for Kunling than for Hyform, which contributes to explaining their different degrees of perceived vulnerability.

\section{The Effect of Perceived Vulnerability on Trust}

Our comparative analysis shows that the level of vulnerability perceived by foreign managers has a negative effect on the levels of trust in the local workforce within the foreign enterprise. In Kunling, the foreign managers' high level of perceived vulnerability led to a low level of trust, as manifested in their policy of refraining from hiring local managers for most top managerial positions. In contrast, at Hyform, the foreign managers' low level of vulnerability triggered a high level of trust, as indicated by the foreign managers' reliance on local partners to run the operation from the outset. We note that vulnerability is an antecedent of trust. Specifically, we find that whether foreign managers approach their own local partners and employees with trust or distrust is predetermined by their perceived vulnerability, which reflects their perception of the environment. Evidently, the higher the perceived vulnerability, the lower is the willingness to trust (i.e., to accept vulnerability). The further steps shown in our model capture how the development of trust is still possible when operating a foreign enterprise in an unfavorable environment.

\section{The Subsequent Development of Trust and Control}

The level of trust in the initial phase of each operation subsequently shapes the agency of foreign managers with respect to how they use internal management activities to compensate for the unfavorable external conditions. Accordingly, in the case of low trust (Kunling), formal control was the focus while social control and active investment in trust were supplementary. In the opposite case of high trust (Hyform), active investment in trust was applied with the safeguard of formal control in the background. In the cases we studied, specific control practices were evident in the use of contracts and rules, and in HRM decisions on the reliance on foreign managers for monitoring. Specific activities that would be evidence of active investment in trust included the transfer of skills and practice through training and socialization, and bonding outside work.

The next step in our model (Figure 1) concerns the behavioral outcomes of managerial agency. In both cases the behavioral manifestation of enhanced competence and commitment in response to controls and trust building activities over time subsequently had a positive effect on the perceived trustworthiness of the local employees. The foreign managers came to see their local employees much more favorably in terms of their competence and benevolence.

Last but not least, we find that the perceived trustworthiness of the workforce within the foreign enterprise moderates the negative effect that perceived vulnerability has on trust. Particularly in the Kunling case, foreign managers' trust has now increased - although vulnerability remains unchanged - because of the increase in the perceived trustworthiness of the local workforce, which renders vulnerability less problematic. Vulnerability is an indicator of the extent to which locals can cause a loss of company resources or harm the firm's competitive position. Trustworthiness is an indicator of the extent to which locals are expected to abstain from doing such harm although they can. This theorizing matches the concept of trust as the willingness to accept vulnerability without eliminating it. The model derived also enables us to distinguish between managerial agency aimed at changing external conditions (environmental strategies), as shown in the literature on institutional entrepreneurship, and interventions intended to improve relationships within the organization (internal strategies), as shown in our case studies.

\section{DISCUSSION AND CONCLUSION}

\section{Theoretical Contributions}

Our analysis makes several theoretical contributions to the study of multinational enterprises in unfavorable environments. First and foremost, it shows the centrality of the concept of perceived vulnerability that links macro influences on the management of foreign enterprises to the 
development of internal trust and control over time at the micro level. Hence our model leads to a revised theorization of vulnerability and trust. In contrast to previous studies that framed vulnerability mainly as a consequence of trust, or as a moderator between trust and risk-taking (e.g., Mayer et al., 1995), we have shown that in the case of foreign firms in transition economies perceived vulnerability is an antecedent of trust, and it is negatively related to trust. This extends prior findings about situational vulnerability and trust in the military context of officer training courses in Israel (Lapidot et al., 2007) to the theory of international management. In addition, we have found that the relationship between perceived vulnerability and trust is actually amenable to managerial agency, as the effect can be moderated over time through the joint use of formal and social control and active investment in trust.

Our proposed model has identified the macrolevel antecedents of perceived vulnerability and the consequences of vulnerability for managerial actions. As such, it enriches institutional theory and resource dependence theory. First, it contributes to a theory of international management within the institutional perspective that envisages a broader range of recursive linkages between purposive action and the unfavorable environments in which multinational enterprises are operating. Without denying the possibility that managerial agency may enact (Boisot \& Child, 1999; Henisz, 2003) or partially construct (Krug \& Hendrischke, 2008; Kostova et al., 2008) the institutional environment in many other contexts, we notice that foreign managers in our cases are either not in a position to or do not seek to change the institutional environment. As Child, Lu, and Tsai (2007) highlight, institutional entrepreneurship in China tends to be driven by the state rather than by other actors. We therefore propose a less heroic managerial stance that is aimed at limiting the consequences of institutional conditions and focuses on exercising agency internally. This contributes to the search for an appropriate concept of agency in institutional theories (see Lawrence \& Suddaby, 2006) that neither overestimates nor underestimates managerial agency within organizational fields. In line with Boisot and Child (1999), but focused on vulnerability as a key concern of management, we find that, in adapting to environmental conditions in China, managers have a choice between trying to reduce vulnerability through control and trying to absorb vulnerability by building trust. Importantly, this is not an either/ or choice but a matter of finding and adjusting a balance between trust and control.

Our comparative study singles out an issue about the theft of a firm's own resources, given unfavorable technological and market environments, which is currently underdeveloped in the resource dependence theory. Our in-depth analysis confirms that the likelihood of proprietary knowledge being leaked has caused wariness among foreign enterprises, as Steensma et al. (2007) highlighted. In addition, we found that the level of technology transferred has a role to play in shaping perceived vulnerability. Other than technological environments, our analysis sheds lights on the market environments that shape the perceived vulnerability of foreign managers. Unlike most authors on international business, who focus on the entry barriers to foreign enterprises in their expansion into host economies (Chen \& Hennart, 2002), we found that it is the level of entry barriers to the industry (in which a foreign enterprise is operating) encountered by the local competitors that shapes the degree of perceived vulnerability of its foreign managers. Moreover, we argue that the level of dependence on local markets also matters. Our comparative study reveals a relationship between the degree of dependence on local markets and the level of perceived vulnerability, which is in line with resource dependence theory (e.g., Pfeffer, 1982).

Essentially, by adopting a multilevel research design, we are able to offer a holistic perspective for analyzing the environmental factors underlying managerial agency. These include the technological, market, and institutional conditions together with the resource dependence. They shape perceived vulnerability, which leads to the use of formal and social control over the local workforce, which subsequently changes the behavior of the workforce. Hence our study contributes to the theorizing of macro-micro linkages by highlighting vulnerability as an important intervening concept.

Moreover, we identify processes of compensating for unfavorable external factors through internal managerial activities in a transition economy. The negative impact of perceived vulnerability on trust can be moderated by combining formal and social control with active investment in trust in a way that matches the underlying perceived vulnerability. First, we show how trust at different levels triggers differentiated controls and active investment in trust (Long \& Sitkin, 2006). Second, we 
empirically support the argument that control can complement trust (Zucker, 1986). As shown by the Kunling case, control could indirectly foster trust, because the locals' compliance with control helped to increase the foreign managers' perceptions of their trustworthiness, which led the foreign managers to trust them more over time despite their own perceptions of vulnerability. We reinforce the view that trust and control are not simply substitutes for each other (Long \& Sitkin, 2006). Even when trust was high or increasing in our empirical cases, formal control was still kept in place as a safeguard. Hence we emphasize that trust and control often coexist and complement each other (Möllering, 2005). Last, our study lends partial support to the transformational models of trust development over time (Lewicki et al., 2006). The case of Kunling features the expected pattern of an initially strong and gradually reduced reliance on control as relationships mature. However, with the case of Hyform we also find evidence that relationships can start off with more relational forms of (high) trust and relatively basic control measures.

\section{Limitations and Future Research Directions}

This study has limitations, but they can serve as stepping stones to future research. As it is based on just two cases, the generalizability of the theoretical model remains to be assessed by applying it to other cases. However, the focus on a small sample was necessary to explore the causal and dynamic relationships of unfavorable environments, vulnerability, trust, and control. The merit of using a small sample of cases to generate theories has been increasingly recognized in international business studies (Kotabe et al., 2007) and management studies (Edmondson \& McManus, 2007; Eisenhardt, 1989).

For reasons of space, we have not spelt out in this article all the testable propositions, but we have clearly illustrated the relationship between variables that are implied by the arrows and boxes in our model (Figure 1). It will be a valuable exercise in future work to make all the empirically generated propositions in our model explicit, to assess them in the light of prior theory, to suggest operationalizations and methods for testing them, and finally to design and conduct a large-scale survey of foreign firms in China and comparative studies of firms in different emerging economies. Meanwhile, our model in its current form holds both preliminary validity and practical value for researchers and managers in international business.
Key opportunities for further research are indicated by dashed arrows in our model (Figure 1), which express possible feedback loops between variables in our model that are not directly evident in our data but may become relevant when much longer time horizons or different types of enterprise are studied (Krug \& Hendrischke, 2008). The dependence of some (large) foreign firms on the local context may well shape the local conditions over time, for example through investment in local education, political lobbying, technology development, and marketing, and through interaction with and pressures on the legal enforcement agencies. Changes in the local conditions that are not caused by foreign firms specifically but by more general transformations may also lead to a recalibration of the variables in the model. For example, ceteris paribus, an improvement in the local education system should reduce the perceived vulnerability of foreign managers.

Moreover, the double-headed dashed arrow between institutional conditions and the perceived trustworthiness of the local workforce within the foreign enterprise suggests that, in the upward direction, an improved perception of the trustworthiness of the local employees within an enterprise (as a result of their behavioral change in response to managerial agency) may spill over and produce a more favorable view of the local workforce and a more favorable assessment of the local work culture and education system over time. In the downward direction, which we can observe to some extent in our data, the arrow in our model shows the effect that institutional conditions give rise to stereotypes of local workers' trustworthiness in general. For example, if managers think that most of the Chinese are opportunistic, this will create perceptual bias against their own employees. A detailed examination of this two-way relationship might focus on whether or not foreign managers see their own employees as exceptions from the stereotypical view of the locals.

Finally, the feedback arrow from managerial agency to dependence on local resources suggests that managerial agency, through an increase in the localization of managerial positions instead of a continued reliance on foreign managers, may increase the dependence on local labor markets, which may raise the level of perceived vulnerability. On the other hand, foreign managers' experiential learning from the local managers and their local social-capital building over time may render their dependence on local resources less problematic, 
making them feel less vulnerable. It is an interesting question for further research to examine whether experience in the foreign context lowers or raises perceived vulnerability and, in consequence, promotes or prevents trust development. In the large-scale survey by Child and Möllering (2003) the length of time that Hong Kong managers had been engaged in the Chinese context had a marginally positive effect on trust. Instead of merely counting the years of experience, we suggest that it is more important to qualify whether foreign managers have had primarily positive or negative experiences in the transition economy. Bad experiences are likely to lead to a heightened sense of vulnerability, while good experiences should be reassuring. Our study has shown that an initially negative cycle can be broken over time by joint investments in trust and control.

In our study we have focused on the relationships between foreign managers and the local workforces that they work with on a day-to-day basis. We have not considered very much the relationships between the owners of foreign controlled enterprises. One might ask whether different forms of ownership have an effect on the motivation of the foreign managers and local workforces. There is a difference in this regard between the wholly foreign-owned Kunling and the 54\% foreign ownership of Hyform. The distribution of ownership has been a long-standing topic in the literature on international joint ventures in China (Child, Yan, $\& \mathrm{Lu}, 1997)$, and has recently been explored in the Chinese context in its effect on trust (Lin \& Wang,
2008). Future research might study whether a larger share of local ownership motivates the local workforce in the enterprise to be more trustworthy (or less), whether a lower share of foreign ownership makes the foreign managers feel more vulnerable (or less), and what the combined effect might be.

As summarized in our model, this study contributes key elements of a theory on the macrolevel antecedents of perceived vulnerability and the consequences of such vulnerability on the microlevel managerial actions within foreign enterprises. It can be extended by future research to capture further aspects of the interplay between managerial agency and environmental conditions.

\section{ACKNOWLEDGEMENTS}

This manuscript is a substantially revised version of the paper that won the Carolyn Dexter Best International Paper Award at the 2007 Annual Meeting of the Academy of Management in Philadelphia. We are grateful to Christopher Paul Earley, Chris Long, Laura Poppo, Peter Smith Ring, Eric Tsang, and Antoinette Weibel; three anonymous reviewers of the Academy of Management OMT Division; Witold Henisz, the editor, and three reviewers of JIBS for very useful comments on the earlier versions of the paper. We thank Eden Ling, Hwee Hoon Low, Kay Heng Phang, Li Li Phua, Derek Tan, Stephen Wan, and Qiu Leong Yew for their research assistance. The research described herein was supported by a research grant from Nanyang Business School, Nanyang Technological University, Singapore and a travel grant from the Max Planck Institute for the Study of Societies, Germany.

\section{REFERENCES}

Alwang, J., Siegel, P. B., \& Jørgensen, S. L. 2001. Vulnerability: A view from different disciplines, Social Protection Discussion Paper Series, World Bank, Washington, DC.

Baier, A. 1986. Trust and antitrust. Ethics, 69(2): 231-260.

Barber, B. 1983. The logic and limits of trust. New Brunswick, NJ: Rutgers University Press.

Bigley, G. A., \& Pearce, J. L. 1998. Straining for shared meaning in organization science: Problems of trust and distrust. Academy of Management Review, 23(3): 405-421.

Boisot, M. 2007. A review of "The resilient enterprise: Overcoming vulnerability for competitive advantage". Emergence: Complexity \& Organization, 9(1/2): 215-218.

Boisot, M., \& Child, J. 1996. From fiefs to clans and network capitalism: Explaining China's emerging economic order. Administrative Science Quarterly, 41(4): 600-628.

Boisot, M., \& Child, J. 1999. Organizations as adaptive systems in complex environments: The case of China. Organization Science, 10(3): 237-252.

Busby, J. S. 2006. Failure to mobilize in reliability-seeking organizations: Two cases from the UK railway. Journal of Management Studies, 43(6): 1375-1393.
Cardinal, L. B., Sitkin, S. B., \& Long, C. P. 2004. Balancing and rebalancing in the creation and evolution of organizational control. Organization Science, 15(4): 411-431.

Chen, S.-F. S., \& Hennart, J.-F. 2002. Japanese investors' choice of joint ventures versus wholly-owned subsidiaries in the US: The role of market barriers and firm capabilities. Journal of International Business Studies, 33(1): 1-18.

Child, J. 2000. Theorizing about organization cross-nationally. Advances in International Comparative Management, 13: 27-75.

Child, J., \& Möllering, G. 2003. Contextual confidence and active trust development in the Chinese business environment. Organization Science, 14(1): 68-80.

Child, J., \& Stewart, S. 1997. Regional differences in China and their implications for Sino-foreign joint ventures. Journal of General Management, 23(2): 65-86.

Child, J., \& Tsai, T. 2005. The dynamic between firms' environmental strategies and institutional constraints in emerging economies: Evidence from China and Taiwan. Journal of Management Studies, 42(1): 95-125.

Child, J., Yan, Y., \& Lu, Y. 1997. Ownership and control in sinoforeign joint ventures. In P. W. Beamish \& J. P. Killing (Eds), 
Cooperative strategies: Asian Pacific perspectives: 181-225. San Francisco: New Lexington Press.

Child, J., Lu, Y., \& Tsai, T. 2007. Institutional entrepreneurship in building an environmental protection system for the People's Republic of China. Organization Studies, 28(7): 1013-1034.

Das, T. K., \& Teng, B.-S. 1998. Between trust and control: Developing confidence in partner cooperation in alliances. Academy of Management Journal, 23(3): 491-512.

Delios, A., \& Björkman, I. 2000. Expatriate staffing in foreign subsidiaries of Japanese multinational corporations in the PRC and the United States. International Journal of Human Resource Management, 11(2): 278-293.

Economist. 2003a. An easy way to lose your shirt. April 3: 24-27. Economist. 2003b. Imitating property is theft. May 17: 52-54.

Economist. 2004. Japan's technology secrets: protecting the family jewels. July 26: 67 .

Economist. 2007. The sincerest form of flattery: Counterfeit cars in China. April 7: 76.

Edmondson, A. C., \& McManus, S. E. 2007. Methodological fit in management field research. Academy of Management Review, 32(4): 1155-1179.

Eisenhardt, K. M. 1989. Building theories from case study research. Academy of Management Review, 14(4): 532-550.

Glaser, B. G. 1998. Doing grounded theory: Issues and discussions. Mill Valley, CA: Sociology Press.

Greenwood, R., \& Suddaby, R. 2006. Institutional entrepreneurship in mature fields: The Big Five accounting firms. Academy of Management Journal, 49(1): 27-48.

Henisz, W. J. 2003. The power of the Buckley and Casson thesis: The ability to manage institutional idiosyncrasies. Journal of International Business Studies, 34(2): 173-184.

Henisz, W. J., \& Swaminathan, A. 2008. Institutions and international business. Journal of International Business Studies, 39(4): 537-539.

Hooghe, I. 1994. Regional economic integration in Yunnan. In D. S. Goodman \& G. Segal (Eds), China deconstructs: Politics, trade and regionalism: 286-321. London: Routledge.

Inkpen, A. C., \& Currall, S. C. 2004. The co-evolution of trust, control, and learning in joint ventures. Organization Science, 15(5): 586-599.

Kostova, T., Roth, K., \& Dacin, T. 2008. Institutional theory in the study of MNCs: A critique and new directions. Academy of Management Review, 33(4): 994-1006.

Kotabe, M., Parente, R., \& Murray, J. Y. 2007. Antecedents and outcomes of modular production in the Brazilian automobile industry: A grounded theory approach. Journal of International Business Studies, 38(1): 84-106.

Krug, B., \& Hendrischke, H. 2008. Framing China: Transformation and institutional change through co-evolution. Management and Organization Review, 4(1): 81-108.

Kwong, J. 1994. Ideological crisis among China's youths: Values and official ideology. The British lournal of Sociology, 45(2): 247-264.

Lapidot, Y., Kark, R., \& Shamir, B. 2007. The impact of situational vulnerability on the development and erosion of followers' trust in their leader. Leadership Quarterly, 18(1): 16-34.

Lawrence, T. B., \& Suddaby, R. 2006. Institutions and institutional work. In S. Clegg, C. Hardy, W. R. Nord \& T. Lawrence (Eds), Handbook of organization studies: 215-254. London: Sage.

Lewicki, R. J., \& Bunker, B. B. 1996. Developing and maintaining trust in work relationships. In R. M. Kramer \& T. R. Tyler (Eds), Trust in organizations: 114-139. Thousand Oaks, CA: Sage.

Lewicki, R. J., Tomlinson, E., \& Gillespie, N. 2006. Models of interpersonal trust development: Theoretical approaches, empirical evidence, and future directions. Journal of Management, 32(6): 991-1022.

Lin, X., \& Wang, C. L. 2008. Enforcement and performance: The role of ownership, legalism and trust in international joint ventures. Journal of World Business, 43(3): 340-351.

Long, C. P., \& Sitkin, S. B. 2006. Trust in the balance: How managers integrate trust-building and task control. In R. Bachmann \& A. Zaheer (Eds), Handbook of trust research: 87-106. Cheltenham: Edward Elgar.
Lu, Y., \& Björkman, I. 1997. HRM practices in China-western joint ventures: MNC standardization versus localization. International Journal of Human Resource Management, 8(5): 614-627.

Lubman, S. 1995. Introduction: The future of Chinese law. China Quarterly, 141: 1-21.

Luhmann, N. 1979. Trust and power: Two works by Niklas Luhmann. Chichester: Wiley.

Luo, Y., \& Peng, M. W. 1999. Learning to compete in a transition economy: Experience, environment, and performance. Journal of International Business Studies, 30(2): 269-296.

Marsh, P. 2004. Fear of high-tech piracy makes some microchip companies cool about China. Financial Times, (London), July 15: 11.

Mayer, R. C., Davis, J. H., \& Schoorman, F. D. 1995. An integrative model of organizational trust. Academy of Management Review, 20(3): 709-734.

Miles, M. B., \& Huberman, A. M. 1994. Qualitative data analysis: An expanded sourcebook, (2nd ed.). Beverly Hills, CA: Sage.

Möllering, G. 2005. The trust/control duality: An integrative perspective on positive expectations of others. International Sociology, 20(3): 283-305.

Möllering, G. 2006. Trust: Reason, routine, reflexivity. Amsterdam: Elsevier.

Möllering, G., Bachmann, R., \& Lee, S. H. 2004. Understanding organizational trust: Foundations, constellations, and issues of operationalisation. Journal of Managerial Psychology, 19(6): 556-570.

North, D. C. 1990. Institutions, institutional change and economic performance. Cambridge: Cambridge University Press.

Oliver, C. 1991. Strategic responses to institutional processes. Academy of Management Review, 16(1): 145-179.

Orr, R. J., \& Scott, W. R. 2008. Institutional exceptions on global projects: A process model. Journal of International Business Studies, 39(4): 562-588.

Pfeffer, J. 1982. Organizations and organization theory. Boston, MA: Pitman.

Ralston, D. A., Egri, C. P., Stewart, S., Terpstra, R. H., \& Yu, K. 1999. Doing business in the 21 st century with the new generation of Chinese managers: A study of generational shifts in work values in China. Journal of International Business Studies, 30(2): 415-427.

Rousseau, D. M., Sitkin, S. B., Burt, R. S., \& Camerer, C. 1998. No so different after all: A cross-discipline view of trust. Academy of Management Review, 23(3): 393-404.

Schweizer, L. 2005. Organizational integration of acquired biotechnology companies in pharmaceutical companies: The need for a hybrid approach. Academy of Management Journal, 48(6): 1051-1074.

Scott, W. R. 2008. Institutions and organizations, (3rd ed.). Thousand Oaks, CA: Sage.

Shapiro, J. M., Ozanne, J. L., \& Saatcioglu, B. 2008. An interpretive examination of the development of cultural sensitivity in international business. Journal of International Business Studies, 39(1): 71-87.

Sheffi, Y. 2005. The resilient enterprise: Overcoming vulnerability for competitive advantage. Cambridge, MA: MIT Press.

Steensma, H. K., Barden, J. Q., Dhanaraj, C., Lyles, M., \& Tihanyi, L. 2007. The evolution and internalization of international joint ventures in a transitioning economy. Journal of International Business Studies, 39(3): 491-507.

Suddaby, R. 2006. From the Editors: What grounded theory is not. Academy of Management Journal, 49(4): 633-642.

Tsang, E., \& Yip, P. 2007. Economic distance and the survival of foreign direct investments. Academy of Management Journal, 50(5): 1156-1168.

Tsui, A. S. 2006. Contextualization in Chinese management research. Management and Organization Review, 2(1): 1-13.

Tsui, A. S., Schoonhoven, C. B., Meyer, M. W., Lau, C.-M., \& Milkovich, G. T. 2004. Organization and management in the midst of societal transformation: The People's Republic of China. Organization Science, 15(2): 133-144. 
Tsui-Auch, L. S. 2004. The professionally managed family-ruled enterprise: Ethnic Chinese business in Singapore. Journal of Management Studies, 41(4): 693-723.

Tsui-Auch, L. S. 2005. Unpacking regional ethnicity and the strength of ties in shaping ethnic entrepreneurship. Organization Studies, 26(8): 1189-1216.

Van Maanen, J., Sørensen, J. B., \& Mitchell, T. R. 2007. The interplay between theory and method. Academy of Management Review, 32(4): 1145-1154.

Wang, J. 2005. Bourgeois bohemians in China? Neo-tribes and the urban imaginary. China Quarterly, 183: 532-548.

Williams, M. 2007. Building genuine trust through interpersona emotion management: $A$ threat regulation model of trust and collaboration across boundaries. Academy of Management Review, 32(2): 595-621.

Yin, R. K. 2003. Case study research: Design and methods. Thousand Oaks, CA: Sage.

Yoshikawa, T., Tsui-Auch, L. S., \& McGuire, J. 2007. Corporate governance reform as institutional innovation: The case of Japan. Organization Science, 18(6): 973-988.

Zaheer, S., \& Zaheer, A. 2006. Trust across borders. Journal of International Business Studies, 37(1): 21-29.

Zucker, L. G. 1986. Production of trust: Institutional sources of economic structure, 1840-1920. In B. M. Staw \& L. L. Cummings (Eds), Research in Organizational Behavior, Vol. 8. 53-111. Greenwich, CT: JAI Press.

\section{ABOUT THE AUTHORS}

Lai Si Tsui-Auch is an Associate Professor of the Nanyang Business School at Nanyang Technological University of Singapore. She received her $\mathrm{PhD}$ in Sociology-Urban Studies from Michigan State University, USA. She is a Hong Kong Chinese by birth and nationality. Her key research interests include multinational enterprises in emerging economies, business groups, and corporate governance reforms. E-mail: alstsui@ntu.edu.sg.

Guido Möllering is a Senior Research Fellow at the Max Planck Institute for the Study of Societies in Cologne, Germany. He received his PhD in Management Studies from the University of Cambridge, UK. A German by birth and nationality, his main research interests include interorganizational relationships, the constitution of markets, and trust. E-mail: gm@mpifg.de. 